\title{
NOTES ON THE FLOWERS OF ANTHOXANTHUM ODORATUM L
}

BY

Theo. Holm.

(With Plate XLviII.)

It is a very interesting and highly instructive task to study the morphology of the Grass-flower. The numerous variations, which occur here are well fitted to confuse our ideas as to the identity of the constituents of the flower, and a mere look into the considerable literature upon this subject is sufficient to prove the difficulty of the study. While some authors have considered the development of the flower as the only reliable guide, others have thought to find the best explanation in the fully but abnormally developed flowers, of which several forms have been recorded in the Graminea. It may not be denied that these aberrant forms, in many cases, are really worthless; but there are, on the other hand, not a few which seem to be of some use to morphological studies. But it would not be necessary to study, for instance, the nature of the glumes of viviparous specimens to find ont that they are identical with bracts, because we are able to see that in the development of these organs; and in a similar instance has Goebel* tanght us that the history of the development of the inflorescence in Cenchrus is sufficient to show that the so-called involucre is an abundantly ramified, but rudimentarysystem of axes, in which each axis aborts and merely shows a spine in the mature flower. Now, in regard to Anthoxanthum the true position of the floral organs and at the same time the morphological identity of these are so much disputed, having been studied from normal flowers, we propose to study the same, but from abnormally developed specimens.

The explanations which have been given by different authors as to the correct understanding of the flower, or rather the spikelet of Anthoxanthum, show a great divergency of opinion. Most commonly the spikelet is described as consisting of one pair of empty glumes, two neutral flowers, represented by two flowering glumes with distinct awns, and finally one perfect flower, of which the flowering glume and the palet are nearly uniform. We have, then, three flowering glumes in the same spikelet which do not resemble each other, a fact that has led to

${ }^{*}$ K. Goebel: Vergleichende Entwicklungsgeschichte der Pflanzenorgane (A Schenk's Handbueh der Botanik, Vol. III, p. 126, 1884.) 
disagreement as to their true morphological identity. While several authors, as, for instance, Kunth, Nees-Von Esenbeck, Torrey, Roeper, Blytt, Hartman, Gareke, Lange, and others have adopted the same explanation as given above, and so strikingly characterized by Roeper* as " Eine Hierochloë, deren männliche Blumen auf die blossen Deckblätter reducirt sind," other authors have come to an entirely different conclusion. Döll † was unable to content himself and to believe that these three glumes, called flowering glumes by the other authors, should represent organs of the same morphological degree, when so different in shape; while otherwise, as for instance in Bromus, all the glumes show nearly the same structure. He therefore came to the conclusion that the fifth and sixth glume (the flowering glume and the palet of the perfect flower) represent the exterior wreath of a perigon, and that all the glumes are then situated on the same axis. This same explanation is also given by Eichler, $\ddagger$ thus agreeing with Döll, who asserts that the flower is terminal on the rhachis, although he admits it to be contrary to the definition of most other authors.

Finally, Hackel§ has described Anthoxanthum as having four empty glumes, but does not mention whether the second pair, the inner ones, represents neutral flowers or not. It would be a very singular case, indeed, if the flower should really be terminal, although Döll's conclusion is very attractive. Schumann, || however, has not hesitated to give the same statement: "Ein Contaktkörper ist auch im auch im Abor nicht anzunehmen, die oberste Bliithe ist echt terminal (Anthoxanthum, Hierochloa)." But the same author seems not quite unwilling to change his idea, if only some "Missbildunzen" (l.c., p. 131) might be produced, of which even Döll seems to have observed two cases.

In offering now a contribution to the explanation of the flowers of Anthoxanthum, the aim will be to show "that the two awned glumes inside the proper empty ones really belong to two neutral flowers," and "that the perfect flower has both a flowering glume and a palet, thereby not being terminal, but lateral." The material, which has served as a base for the present investigation, was collected in the Smithsonian park in this eity. In regard to the locality where the specimens were collected the ground had lately been overflowed, so that in this fact the cause of the malformation might be found, especially since no other factors were observed, neither parasitic fungi nor insects.

The general appearance of the plants was quite remarkable; the culms were much taller than usual, the inflorescence very long, loose,

* Joh. Roeper: Zur Flora Mecklenburgs, 1844.

†Döll: Beiträge zur Pflanzenkunde. Mannheimer Jahresbericht, 1868.

$\ddagger$ A. W. Eichler: Bliithendiagramme, 1875 .

§. Hackel : The true Grasses, translated from "Die natiurlichen Pflanzenfamilien" by F. Lamson Seribner and Effie Southworth, 1890.

|| Karl Schumann : Neue Untersuchungen iiber den Bliithenanschluss, Leipzig, 1890. p. 128 , ete. 
and nodding, while from the apical spikelets slender branches issued, terminated by a few, (1 to 4) small spikelets (Tab. XLVIII, Fig. 1$)$. In some specimens the spikelets were transformed into leafy shoots, thus rep. resenting the well-known variety "vivipara," as described for many species of Graminea (Tab. xLVIII, Fig. 12).*

Now, concerning the first question, whether the two awned glumes represent two neutral flowers or not, let us examine figure 8 on the accompanying plate. This spikelet, of which the proper empty glumes have been removed, shows altogether three awned glumes, but of which only the two basal ones are now in question. They are both situated on the same rhachis, but at different heights, and we see farther that the uppermost one, that on the right side in the figure, partly encloses another smaller and awnless glume, which is a normal palet. Judging from the position and the shape of these two glumes in connection with the fact that one of them has been found enclosing a palet and flower, may we then not suggest that they both are true flowering glumes? There is no doubt that they correspond to the two similar glumes of the normal spikelet, because their position is exactly the same, and there is no essential difference in regard to their appearance; they were, it is true, merely hairy along the midrib, but this character is of but small importance. Several other variations were observed even in the same inflorescence, a circumstance probably due to the unusual moist locality where the plants were found growing. In some other spikelets, (Figs. 2, 9 and 10) only one of these glumes was developed, but it was easily recognized. We have now another case (Fig. 4) in which we see the same glumes again, but widely separated from each other on the same rhachis. Their form is here very different from the normal one, since they are distinctly acuminate and but shortly awned. We meet here a fact which shows that their form may not be constant, and also that they may resemble the proper empty glumes. This very abnormal case would have been a good support to Döll's theory that these glumes should not be equal to the fifth glume in the normal spikelet, since they are not only very different from this in regard to their shape, but in this case, they even resemble the empty glumes. We venture, however, to oppose this supposition of Döll by referring to the spikelet in Fig. 8. There are here three awned glumes, the uppermost one being a true flowering glume which has here simulated the shape of the others, and which really corresponds to the same glume of the normal perfect flower. It is situated upon the same rhachis as all the other glumes, the empty and the flowering ones of the neutral flowers, and encloses a palet and a rudimentary pistil, but no stamens. This was observed in several other spikelets, and we see it illustrated again in Fig. 6, where the uppermost flowering glume is easily distinguished by its long awn, although the glume itself is much smaller than the others.

${ }^{*}$ Compare E. H. Hunger: Ueber einige vivipare Pflanzen und die Erscheinung der Apogamie. Inaug. dissertation, Bautzen, 1887.

Proc. N. M. 92 $-26$ 
It may not be unreasonable to suppose now, that the spikelet of Anthox. anthum has three flowering glumes, although we have been unable so far to observe any trace of a palet or rhachilla in the axil of the lowest situated of these glumes.

We now want to reply to the next question and show whether the perfect flower, the uppermost one in the spikelet, is terminal, as stated by Döll, Eichler, and Schumann, or lateral. It is hardly necessary to offer any further discussion concerning this point, since it is a simple consequence of what has been shown in the two spikelets-Figs. 6 and 8 ; because we have seen in Fig. 8 that a palet is present, and thereby a rhachilla indicated, besides that in both figures the rhachis is distinctly elongated above the base of the flowering glume (Fig. 7), and shows here a pointed processus, as usual in the spikelets of the Graminea.

Although, as stated above, abnormally developed specimens have been used to demonstrate the morphological identity of the organs in the normal spikelet of Anthoxanthum, it may not be denied that the comparison seems to favor the generally adopted idea that the spikelet really contains three flowers, but of which only one is perfect, and that this same flower is not terminal but lateral. Before leaving the subject we wili call attention to a very peculiar malformation observed in some of the examined specimens. An abnormally developed flowering glume of one of the neutral flowers (Fig. 11), the apex of which showed not only a long and strongly bent awn, but also on each side of this awn was an appendage, the structure and shape of which reminds one very much about the glume itself. We have then in this glume the same kind of prolification, of which similar cases have been recorded by Masters.*

The large number of truly viviparous spikelets examined did not show anything of particular interest; it might be noted that in these, as in all the other malformed spikelets, the empty glumes had constantly preserved their usual and normal appearance.

U. S. National Museum,

Washington, D. C., March 21, 1892.

\section{EXPLANATION OF PLATE XLVIII.}

Anthoxanthum odoratum $\mathrm{L}$.

Fig. 1. Inflorescence with proliferous spikelets, natural size.

Fig. 2. Proliferous spikelet from the apex of the inflorescence, magnified about four times. The empty glumes are normally developed, while the flowering glumes of the neutral flowers are reduced to one; the rhachis is strongly elongated and bears at its apex three spikelets, the median nearly sessile, the two lateral ones distinctly pediceled, all surrounded by normal empty glumes.

Fig. 3. Spikelet $a$ of the preceding, showing a normally developed spikelet with one pair of empty glumes, two awned flowering glumes of the neutral flowers, and a perfect flower with the flowering glume and palet of the same shape. c. $4 \times$ natural size.

* Maxwell Masters: Vegetable Teratology, London, 1869. 
Fig. 4. Proliferons spikelet from the base of the inflorescence, showing the two empty glumes, the two flowering glumes of the neutral flowers, which are here separated from each other and situated on an elongated rhachis. The apex of the rhachis bears a very rudimentary spikelet; the perfect flower is here represented by two small scales (flowering glume and palet) and a very rudimentary pistil with two stigmas. c. $4 \times$ natural size.

Fig. 5. Branch with four spikelets fiom another inflorescence. c. $4 \times$ natural size.

Fig. 6. Spikelet $b$ of the preceding figure, showing the empty glumes, tie flowering glumes of two neutral flowers, and a strongly elongated rhachis, which bears, a little below its apex, a rudimentary flower. e. $4 \times$ natural size.

Fig. 7. The upper part of the rhachis of the preceding spikelet, showing the distinct, pointed apex of the rhachis, and a lateral flower, consisting of one stamen and one stigma; the palet is absent, but the flower is supported by a flowering glume with long awn. e. $15 \times$ natural size.

Fig. 8. Spikelet $c$ from the inflorescence, shown in Fig. 5. The empty glumes have been removed to show the other parts more distinctly. There are here three distinct flowering glumes of about the same size and shape; the two lowest belong to the two neutral flowers, but of which the one at the rigbt side in the figure encloses a palet. The rhachis is slightly elongated, and bears a third flowering glume, which also includes a palet and a rudimentary pistil, but no stamens. The rhachis is extended a little above the base of the uppermost flowering glume and is sharply pointed. This figure shows the lateral position of the perfect flower. c. $4 \times$ natural size.

Fig. 9. Spikelet $d$ of the inflorescence in Fig. 5. There is here, besides the two empty glumes, only one flowering glume of the neutral flowers; the other one is entirely wanting. The perfect flower has the flowering glume and the palet of the same shape as in normal spikelets, but only one stamen and no pistil. c. $4 \times$ natural size.

Fig. 10. Spikelet from another inflorescence with but one flowering glume inside the pair of empty glumes. c. $4 \times$ natural size.

Fig. 11. An abnormally developed flowering glume of a neutral flower, showing at its apex a long, bent awn and two glumaceous, awned appendages. c. $4 \times$ natural size.

Fig. 12. A truly viviparous spikelet with normal empty glumes, while the other glumes have been transformed into green leaves. c. $4 \times$ natural size. 


\section{$2 \mathrm{BHL}$ Biodiversity Heritage Library}

Holm, Theodor. 1892. "Notes on the flowers of Anthoxanthum odoratum L." Proceedings of the United States National Museum 15(910), 399-403. https://doi.org/10.5479/si.00963801.15-910.399.

View This Item Online: $\underline{\text { https://www.biodiversitylibrary.org/item/53607 }}$

DOI: https://doi.org/10.5479/si.00963801.15-910.399

Permalink: https://www.biodiversitylibrary.org/partpdf/52699

\section{Holding Institution}

Smithsonian Libraries

\section{Sponsored by}

Smithsonian

\section{Copyright \& Reuse}

Copyright Status: Public domain. The BHL considers that this work is no longer under copyright protection.

This document was created from content at the Biodiversity Heritage Library, the world's largest open access digital library for biodiversity literature and archives. Visit BHL at https://www.biodiversitylibrary.org. 